\title{
Elizabeth Bishop and the Villanelle: One Art, an Ocean, and Two Languages
}

Michelle Gadpaille, Tomaž Onič

Faculty of Arts, University of Maribor, Koroška cesta 160, SI-2000 Maribor, Slovenia michelle.gadpaille@um.si, tomaz.onic@um.si

The genesis of this study lies in Elizabeth Bishop's famous poem, "One Art." A villanelle, it stands out luminously against the background of contemporary poetics, the lingering legacy of modernist free verse and the many branches of experimental post-modernist poetry in the United States. It stands apart, with Theodore Roethke among the few precursors, claiming a traditional fixed poetic form-the 6-stanza villanelle-as a valid medium for expressing the late-twentieth-century concerns of a scholarly, peripatetic, lesbian poet. Formally, it is an anachronistic appropriation; aesthetically, it is a triumph. The questions triggered by Bishop's poem and explored by this paper are three-fold: first, the adequacy of existing terminology for defining the refrain, where we propose the need for a new term: polysemic repetend. Our second question addresses the perceived global influence of "One Art." We then turn to the presence of the villanelle in Slovenian poetics and consider how Bishop has been translated, since we assume that the formal complexity of the metrical and rhyme arrangement will present a challenge for the translator (Veno Taufer). The study thus works towards a modest appreciation of parallel New Formalist aesthetics between American and Slovenian poetry.

Keywords: American poetry / Bishop, Elizabeth / vilanelle / refrain / polysemic repetend / Slovenian translations / Taufer, Veno

To write a villanelle in contemporary America is to scratch the itch for formalism...

\section{Introduction and aims}

Bishop's poem, a villanelle, is called "One Art," but the artistry involved is, of course, neither single nor simple-though undoubtedly "singular" in the other sense of the word. The poem contradicts, in a

${ }^{1}$ Amanda Lowry French, Refrain Again: The Return of the Villanelle, 2004 
way, the claim of its title, for it is manifestly not born of a single art, nor can it be critically analyzed without calling on several arts simultaneously: from music ${ }^{2}$ to poetics, from Italian to French, English and Slovenian, and from prosody to translation theory. Moreover, the word "art" in the title shimmers with polysemic potential. In the OED, the entry for art lists fourteen senses for this substantive, some of which themselves contain sub-senses. Joining the esthetic to the pragmatic, "art" in its many senses destabilizes, even contradicts, the unified certainty of the numeral "one" that precedes it. One skill, perhaps, but just one art-impossible.

Like many outstanding poetic artifacts, Bishop's "One Art" claims its interpretive space so completely that it is tempting to read it in isolation from its poetic context. Interpretations of this poem have tended to read it back into Bishop's personal life (Spivack, Shapiro) and to see its meditation on the varied forms of loss as reflecting Bishop's geographical and interpersonal movement away from the loved anchorwhether place or person. The aim is to fill in the opposite page: to read this poem back into its formal context, looking back to the poetic form/formula as exploited by previous writers, and then forward to check the poem's potential echoes, even in Slovenian translation.

"One Art" has become known as one of the "top" American poems, ${ }^{3}$ one of the most frequently read, consulted and downloaded in our easyaccess digital age (for the view from Britain, see Parini). It would not be hyperbole to claim that for the casual online reader, "One Art" represents American Poetry, right up there along with "Song of Myself" and "Stopping by Woods on a Snowy Evening." It has become one of the few pieces of artistry that both the lay and academic reader can enjoy and admire. Brett Candlish Millier singles it out within its genre, calling the poem "the best modern example of a villanelle" (Millier 122), while David Shapiro and Kathleen Spivack both call it a masterpiece outright (Shapiro 77; Spivack 506). Herself a poet, Spivack praises it as

${ }^{2}$ The name "villanelle" originated in the word for a type of rural Italian music (French, Refrain 21; Kane 428), although no convincing argument has been advanced that the highly prescriptive poetic form shared that origin. Nevertheless, the repetitive, incantatory nature of the villanelle lends itself to musical treatment. See Leonard Cohen's 2004 version of a tetrameter villanelle by his fellow Canadian, F. R. Scott, "Villanelle for Our Time." When treated as lyrics, the repeated lines are less marked and resemble a traditional chorus by the end of Cohen's performance.

${ }^{3}$ See, for instance, Michael R. Burch's The Best American Poetry of All time; The Best Villanelles of All Time and The Top Ten Villanelles in the English Language, available at site HiperTexts. The PoemHunter site also lists "One Art" in its top hits, with a user "rating" of 9.28 . 
"a poem so lovely that [it] is almost sacrilege to talk about it" (Spivack 506). Sacrilegiously, we will tackle the poem's quality and potential trail of influence in the decades since. The issues addressed in this paper require the skills and languages of both authors and are three-fold:

1) Bishop's achievement in her version of the villanelle-which necessitates an excursus into the question of genre and form, especially the definition of refrain.

2) Whether Bishop's use of this unusual poetic form had an impact on American poetry written in the next two decades, or fostered a trend to the villanelle under the aegis of the New Formalism.

3) How "One Art" has been translated into Slovenian.

\section{Individual achievement and genre innovation}

Although Bishop once claimed that the poem "just came to her" as if in a dream (Millier 123), there still exist seventeen drafts of the poem (Millier 123; Spivack 506), which are housed in a collection at the Vassar College library (Spivack 506). Spivack, who knew Bishop personally at Harvard, is convinced that the surviving 17 drafts comprise only a partial record and that there were many more in the wastebasket.

This record gives ample evidence of the poet's craft, of the "tremendous selectivity" that Millier identifies in the poem's "minimal words" (Millier 127). Such meticulous craft, however, did not result in a poem that followed scrupulously the formal prescriptions of the villanelle. Setting aside for the minute that the villanelle is not genuinely medieval and lacks, as one scholar has proven at length, a truly "fixed" form (Kane), there is still something radically individual in Bishop's stamp on the genre in "One Art."

From the opening stanza of "One Art," Bishop smoothly juggles her three great themes of loss, ${ }^{4}$ mastery and disaster:

The art of losing isn't hard to master;

so many things seem filled with the intent

to be lost that their loss is no disaster.

By the final stanza, actual creative disaster has been narrowly averted, and mastery of loss and of the poetic medium has been snatched, seem-

${ }^{4}$ Hirsch observes that the "compulsive return" of the villanelle is particularly suited to a poetry of loss (Hirsch 349). 
ingly with an act of supreme authorial will, from the emotional and lexical chaos that threatens to overwhelm the geometry of the fixed form:

—Even losing you (the joking voice, a gesture

I love) I shan't have lied. It's evident

the art of losing's not too hard to master

though it may look like (Write it!) like disaster.

(Bishop, Complete Poems)

Neither the poem's colloquial tone nor its interpolated self-address or self-revision were new in Bishop's practice, since both characterize her poetic oeuvre (Millier 125-126). Even the villanelle form had been attempted before by Bishop, as early as 1949 or 1950 (French, Refrain $147,171-72) . .^{5}$ Its rhetorical presentation as a kind of argument with oneself is predated by Dylan Thomas's "Do Not Go Gentle," which follows "the classic model of rational argument" according to French (French, Refrain 177, 182).

What, then, accounts for this poem's status? We will argue below that the complex answer begins with Bishop's evocation of common humanity, her fusion of the poetic and the human struggle, and the manifest wrestle with the demands of the fixed form. Bishop's poem constitutes in one sense an anti-villanelle, in its contest with the stubborn rhyme desert of the English language and the inflexibility of meter. Nonetheless, Bishop's voice here, however anguished, has not despaired or surrendered, which is the claim in the playfully titled villanelle "The Thing's Impossible" by Bruce Bennett. Post-modern negation allows Bennett to excuse the circularity of the repeated lines demanded by the form: "Don't write a villanelle to tell a tale. / The thing's impossible. You're bound to fail!" Conversely, Bishop persists, to wrest mastery from looming failure, in the process etching her emotional struggle in that technically flawed final line. The cry within the parentheses "(Write it!)" emerges through clenched teeth, to affirm for the reader that, though tragedy was near, no soap-opera disaster marks this experience and that the human will can after all exert control over a life course marked by loss and emotional chaos. The poem can, in short, be read as a "hurting song," a motif common to many countrymusic anthems.

While the popular readership may respond to this layer of meaning, there remains the fact of Bishop's formal generic deviation. In

${ }^{5}$ Bishop was working on an earlier villanelle about an aviary in 1963 and 1964 (French, Refrain 172). 
order to assess the poet's achievement in deforming and reshaping the once-obscure genre, we need to trace the history of the villanelle in the decades leading up to Bishop's adoption of the form.

The villanelle in the 1970s was still perceived as an artificial nineteenth-century form once exploited by the decadents such as Edmund Gosse and Ernest Dowson (French, "Edmund Gosse"; Alkalay-Gut 101) and largely neglected by modernists because of its perceived frivolity (Alkalay-Gut 101; Hirsch 349), effeminacy (French, "Edmund Gosse" 260) and decorative mysticism (Geckle 90). In the modernist novel Portrait of the Artist as a Young Man (1916), James Joyce gave his young hero Stephen Dedalus a villanelle to express his swooning adoration of a dream lady (Roos; Geckle) and its sordid consummation, but also to indicate that Stephen clung to outmoded language and forms and had far to go in his poetic craft. Joyce/Stephen's poem ("Are you not weary of ardent ways") is an example of youthful excess, filled with as much masturbatory subtext as earnest Mariolatry. Although it is among the most familiar examples of the villanelle form (and, along with its surrounding novel, widely translated into world languagesincluding Slovenian), it marks a dead end in the development of the form, a tribute to a mode that was even then vanishing before the onset of modernist free verse.

Certainly, the villanelle slumped in popularity during the period of high modernism (French, Refrain 147) but survived in isolated works by American poets such as William Empson, Weldon Kees and W. H. Auden, before a sudden mid-century invigoration involving individual masterpieces by Dylan Thomas and Ted Roethke. ${ }^{6}$ In our extensive research for this paper, an attempt was made to chart the occurrence of villanelles in an objective manner. ${ }^{7}$ Results certainly indicated that the 1930s and 1940s yielded few villanelles, while the 1980s saw a rise in their popularity and the 1990s an undeniable explosion of instances of published villanelles. Since the turn of the millennium, numbers have doubled, as poetry becomes digital and democratized in online forums. Nevertheless, these numbers cannot be taken as accurate indicators of absolute gains in popularity, since they say nothing about the ratio of villanelles to the incidence of other fixed poetic forms or to free verse, or to poetic activity in general. The rise in villanelle numbers could

${ }^{6}$ See French (Refrain) and Kane for a survey of villanelle history, right back to the pseudo-medieval origins, through its artificial definitions in various poetic handbooks and adoption by the decadent poets, to its twentieth-century manifestation.

${ }^{7}$ Research was carried out at the British Library Reading Room in Boston Spa, UK, making use of the British Library's extensive print and digital holdings. 
plausibly indicate nothing more than the increase in journals that publish poetry, in online platforms for amateur poetry and in the teaching of the fixed form in creative writing courses.

More indicative are the anthologies of villanelles and of literary criticism on the topic of villanelles. Being less subject to the pressure of amateur online presence, such publications yield a less spectacular but more thoughtful outline of engagement with this poetic form over the decades. A chart of critical writing about villanelles reveals that the topic took off in the mid-1970s (Bishop's "One Art" appeared in 1976) and that critical interest increased after the turn of the century and has maintained that level since. Individual critical publications do stand out, such as Amanda French's 2004 thesis on villanelles, or Kane's rebuttal (2003) of the legendary pedigree of the villanelle.

Whatever the artificiality of the form's prescriptive definition, it entered the twentieth century as a fixed form, with two repeated lines and a definite, restricted rhyme scheme. Recent scholars have offered a useful "formula" (what Ellingsen calls an "algorithm") for understanding the "rules" of the six-stanza villanelle (Hirsch 349; Ellingsen 42; Jason 137). Moreover, in Slovenia, Boris A. Novak also lays out the pattern for a villanelle, in the extensive theoretical notes accompanying his poetry collection Mojster nespećnosti (58-59) as well as in several of his monographs of traditional set poetic forms, e.g., Oblike duha (514517). ${ }^{8}$ Most villanelles of the late nineteenth century and twentieth century adhered to the pattern of two refrains that recurred identically (e.g. W. H. Auden, Weldon Kees and William Empson), thus reinforcing the case for a fixed poetic formula.

Nevertheless, the very existence of rules has been contested by critics and literary historians (see French Refrain; Kane 2003), while modern fans of the poetic form often endorse the formal prescriptiveness the villanelle offers, even while treating the rules more as guidelines.

The prime formal imperatives of the villanelle comprise tercets, end-rhyme with an ABA pattern and two "refrains" (the meter is variable, although iambic pentameter is common). ${ }^{9}$ We place the word "refrain" in quotation marks because it is immediately debatable whether the two repeated lines qualify as refrain in the standard poetic sense. Abrams's Glossary of Poetic Terms, for instance, defines refrain as

${ }^{8}$ The New Formalism movement that has contributed to a revival of set poetic forms is, in the Slovenian context, referred to and contextualized by Novak Popov and Pavlič. Research into Slovenian poetics was partly completed by Denis Režonja, from the Department of English, Faculty of Arts, Maribor.

${ }^{9}$ See Marilyn Taylor for an engaging summary of the villanelle imperatives. 
follows: "A line, or part of a line, or a group of lines, which is repeated in the course of a poem, sometimes with slight changes, and usually at the end of each stanza" (306). The words "slight" and "usually" point to the problems in classifying Bishop's repeated lines as refrains, especially the second refrain.

In the case of Bishop's "One Art," the treatment of the second refrain differs in exhibiting not slight, but extreme variation. At first glance, it seems that this villanelle has only a repeated rhyming word (disaster), rather than a refrain per se. However, this opens the question of what exactly IS the refrain, per se.

The terminology of repetition in the villanelle needs to be tackled from the perspective of both form and function. Critics and encyclopedic authorities distinguish burden, from chorus, from refrain, ${ }^{10}$ and a new term "repetend" was created by Laury Magnus at the end of the 1970s to capture poetic repetition that varied and extended meaning, while creating the illusion of time passing (Magnus 10-12; Hirsch 251). Explicitly linked to the villanelle in Magnus's philosophical analysis, the repetend concept serves to capture the suppleness of the repeated lines in the most complex villanelles, because Magnus demonstrates how even "identical repetition" can bring about "important semantic changes" (12). A varied refrain appears in Roethke's villanelle "The Waking," where the line changes from "I learn by going where I have to go," through "And learn by going where I have to go" ultimately to "And, lovely, learn by going where to go" (in Roethke, Collected Poems). Many recent poets have embraced the flexible second refrain explored by Roethke and extended by Bishop. In "One Art," however, the modulations are extreme: from "to be lost that their loss is no disaster," through "to travel. None of these will bring disaster," and "I miss them, but it wasn't a disaster," to the grimly self-reflexive final line "though it may look like (Write it!) like disaster" (Bishop).

Clearly, Bishop deviates from exact repetition in a manner that feels different from the subtle, incremental changes in Roethke's poem. Her second repetend displays syntactic, lexical and pragmatic variations, ones which, together with punctuation changes, effect semantic change. Other poets have inserted variant second refrains, with, for instance, slant rhyme instead of exact rhyme, or word-substitutions (see, for example Bennett's “The Thing's Impossible”). Scholar Philip K. Jason claims that "punctuational variation" is the most common means

${ }^{10}$ See Chris Baldick's Oxford Dictionary of Literary Terms (2008); it contains a brief entry for repetend, which is clearly distinguished from refrain. 
by which contemporary poets modulate the repetend (Jason 143). Punctuation, however, is the subtlest of the variants, though implicated in both syntax and meaning, as in "One Art." Despite extensive metamorphosis, Bishop's multiply variable line remains identifiable as the second "refrain" of the villanelle. This capacity to retain identity or allusion while adopting new signification resembles the process seen in memetic variation in contemporary culture. In memes, a core feature of the original must be kept, but rider effects can be varied (Gadpaille). Similarly, the villanelle's second refrain line has acquired the ability to absorb certain types and amounts of variety, without losing the effect of repetition and thus retaining the villanelle characteristics. Like a clever meme, then, Bishop's poem evokes something familiar, only to re-purpose it with extreme variation that approaches parody.

Consequently, it is necessary to have a new term for Bishop's kind of repetition effect; refrain is too general, repetend more specific but failing to capture the polyvalent nature of the lines we seek to describe. For, the repeating lines in a villanelle do not even occupy the same places in the tercet structure. They can be the first line, the last line or the second line. This distinguishes them from other types of refrain or chorus. Edward Hirsch, author of the Essential Poet's Glossary and himself a poet, has used the term "rotating refrain" in reference to a similar effect in his own poetry (Segal). For critic John Hollander, the new refrain even takes on a meta-poetic character, "troping" the scheme of refrain (Hollander 74). With these theoretical concepts and Bishop's "One Art" in mind, we thus suggest a new term-polysemic repetend-for the second repeated line in the contemporary villanelle.

Since, therefore, Bishop's "One Art" demands new poetic terminology for its analysis, it is clearly innovative in its treatment of an unfashionable poetic form and can thus be suspected of exerting a schemarefreshing effect on its poetic successors.

\section{Bishop's impact on American poetry and the New Formalism}

Scholars working on Bishop, or on the villanelle, repeatedly aver that her poem "One Art" exerted an influence on succeeding poetry and may even have initiated rather than merely heralding the New Formalism movement in American poetics. Amanda French maintains that "One Art" made the villanelle "contemporary, postmodern, popular" (French, Refrain 185). Willard Spiegelman, himself a distinguished 
journal editor, spoke of Bishop's "legacy" along with that of James Merrill. To give New Formalism a foundation in fact, Spiegelman generated statistics by counting poems as either "formal" or "non-formal" over 40 years of magazine publication; in the end, he was unable to confirm a trend-in 1991-towards greater formalism in American poetry. Nevertheless, he still maintains that "it may be possible to trace at least some habits of the 'new' poets to the practices of Bishop and of James Merrill" (Spiegelman 157). French explicitly places "One Art" at an influential crux in American poetry: "After Elizabeth Bishop's 'One Art' of 1976 and the rise ... of New Formalism, the names of major, minor, and very minor American, British, and Irish poets who have written and/or published a villanelle become too numerous to catalogue" (French 262). That "One Art" was followed by this explosion of villanelles does not, of course, mean that it caused the trend; literary influence in the short term is an ephemeral thing, the subject of anecdote and subjective opinion on the part of those with various aesthetic agendas. Following Spiegelman, we thus conducted a survey and found that poems identifiable as villanelles (either by title or in the keyword search) had appeared in almost every literary journal or review in the United States in the 45 years since "One Art." ${ }^{11}$ Before that, the appearance of villanelles was sparse and connected to particular journals, possibly to the individual taste of an editor. After the turn of the millennium, villanelles also began to appear in anthologies, viz. Kelly Deacon's Rhyme, Rondeau and Villanelle (2000). At the same time, the form took its place in the journals and anthologies associated with American New Formalism. ${ }^{12}$

${ }^{11}$ Journals that have published identifiable villanelles include, but are not limited to, the following: Agni, Ambit, The American Poetry Review, Antipodes, Chicago Review, Christianity and Literature, Columbia: A Journal of Literature and Art, Cross Currents, The English Journal, The Georgia Review, Harvard Review, The Hudson Review, The Iowa Review, Italian Americana, The Kenyon Review, The Langston Hughes Review, Massachusetts Review, Math Horizons, Mississippi Review, New England Review, The North American Review, Obsidian III, Ploughshares, Poetry, Prairie Schooner, Rhetoric Review, The Sewanee Review, and The Virginia Quarterly Review. A few journals stand out for their support for this poetic form, especially Prairie Schooner, which was publishing villanelles in the 1930s and still doing so after the turn of the millennium. French made her own count and concluded that "over a hundred villanelles have been published in reputable literary journals and books since 1985" (French, Refrain 15). See Hirsch's Essential Poet's Glossary for a concise list of modern American villanelles (Hirsch 2017, 349).

${ }^{12}$ Journals associated with the movement include The Reaper, The New Formalist and The Formalist: A Journal of Metrical Poetry and Measure: A Review of Formal Poetry. 
Moreover, if one ventures to the wild west of online poetry (sites such as PoemHunter), one finds that amateur villanelles are plentiful, though of varied quality. By 1980, Philip K. Jason could claim that there was "lively interest" in this particular poetic form (Jason 136), while by 2010 , French found the term to be "a staple of poetry handbooks" (262). For poetry amateurs, there are even YouTube and wikiHow entries that teach the intricacies of the villanelle form.

Many contemporary writers have adopted the villanelle-why is something about which one can only speculate, without extensive interviewing of numerous practitioners. There are however a few hints in the topic and lexicon of the modern villanelles. In Deacon's anthology, for instance, the 41 poems show evidence of influence by earlier villanelles (a response to Dylan Thomas called "Rage On"; Deacon 81). There is a proliferation of contemporary themes, but a tendency to use archaic lexis and syntax (words like nay, methought, and the use of $y e$ and thee), indicating that some inexperienced twenty-first-century writers think of the villanelle as an ancient form, to be preserved and imitated rather than extended.

Contemporary deployment of the villanelle tends to be self-conscious, with many instances having the word "villanelle" as the title, in the title or as the subtitle. Examples include "The Unrhymed Villanelle" by Matthew Mead (1999), "Wedding Villanelle" by Mark Jarman (2008), "Little L.A. Villanelle" by Carol Moske (1992) and "Villanelle after Wittgenstein" by H. L. Hix (1991). This self-consciousness shows up additionally in meta-poetic themes, as in Elisavietta Ritchie's "How to Write a Villanelle" (2002), which is itself a rough-cast villanelle, Helen Cerne's "Villanelle: A Writer's Hell," or Bennett's “The Thing's Impossible" (2011), which highlights the poet's struggle with the constraints of the genre. Also in evidence is a modern trend to vary the meter, everything from the more traditional pentameter and tetrameter to trimeter and a long, loose, Whitmanesque line, all of which are traceable in Kelly Deacon's anthology. Deacon's modern, amateur writers apparently found in the villanelle the support of form, alongside the permission to make individual variations, and that may be the key to the form's contemporary popularity.

French mentioned handbooks as the provenance of the villanelle, and her observation is telling. With its prescriptiveness, it is an eminently teachable form, endlessly imitable, even by writers with little experience. American colleges and universities foster a subject called "Creative Writing"; it may be there that the villanelle is incubated, in myriad creative writing seminars across American campuses. Evidence 
for this theory accrues from a search for "villanelle" in articles about college courses in composition and creative writing: Vertreace (1997); Schneiderman (2002); Rogers (2006); Taylor (2008); Northrop (2010) and Ellingsen (2011). There is thus some evidence, though not statistically relevant evidence, that the villanelle has become a teaching tool in American writing courses.

In 2017, villanelles in general and Bishop's profile in particular were boosted by three publications: a critical monograph, Amanda French's Refrain Again: The Return of the Villanelle and two magazine features, Frankel's "Coming to Terms with Loss" in the Atlantic, and Roth Pierpont's "Elizabeth Bishop's Art of Losing" in the New Yorker. Capturing the attention of two premier American magazines for the $40^{\text {th }}$ anniversary of the publication of "One Art" indicates the perceived significance of the poem and its anniversary. Critics certainly regarded Bishop and her villanelle as influential on a younger generation.

\section{Translation of "One Art" into Slovenian}

The Slovenian translation of "One Art" ("Ena umetnost") appeared in a 2007 publication entitled Zemljevid (The Map) containing a selection of Bishop's poems and short prose pieces from several collections including North \& South (1946), A Cold Spring (1955), Questions of Travel (1965), Uncollected Work (1969), Geography III (1976), New Poems (1979)_-published in the year of the poet's death—as well as from the posthumously published Edgar Allan Poe \& The Juke-Box, Uncollected Poems, Drafts, and Fragments. The poems and the few prose pieces were selected by Primož Cučnik, who also edited the volume, and were translated by Čučnik himself as well as by Boris A. Novak, Ana Pepelnik and Veno Taufer.

Translation of poetry can never be seen as an easy task, and in the case of "One Art" the translator (Taufer) seems to be facing a particularly demanding undertaking. On the one hand, there is the poem's thematic complexity, leaning primarily on specific lexical choices (loss, mastery, etc.) that allow for broad interpretive potential, and on the other, there is Bishop's use of the traditional villanelle form, including her creative variation of one of its refrains. We will address this complex translation challenge by perusing the most salient individual translation issues in isolation, yet with full awareness that the translator's final output cannot accommodate these aspects detached from the others but—as is always the case-must embody them in one product. 
Starting with the villanelle form, the aspects to consider include primarily the double refrain, the rhyming pattern and the iambic metrical scheme. Apart from the latter, which this discussion will prove a major and practically unfathomable translation obstacle, the other formal features are accomplished by the Slovenian translator with considerable success. Bishop's second refrain-previously named the polysemic repetend - is masterfully varied in the original, and it retains most of the variation in the target language as well. The syntactic switch between disaster as subject of the sentence and as direct object is absent from the translation; however, the pragmatic and lexical variation effecting semantic change is still there. The alteration of the first refrain at the end of the poem ("too hard to master" instead of "hard to master") is successfully preserved, unsurprisingly, in all aspects other than the metrical.

The embracing rhyme pattern (aba) in the three-lined stanzas of the villanelle form, usually referred to as enclosed tercets, is varied in the last, four-lined one (abaa). This restriction would not seem unattainable in translation were it not combined with (1) the two villanelle refrains, the endings of which need to conform to this rhyme scheme, consequently requiring that the refrain endings rhyme, ${ }^{13}$ and (2) the mostly effective and powerful line-closing expressions or phrases that cannot be denied important semantic or thematic potential. Since in practice these allow little leeway in terms of lexical choices, they represent a considerable restriction for the translator. In "One Art" the refrain lines end with master and disaster, a rhyming pair that has no straightforward (rhyming) counterpart in Slovenian. Moreover, both concepts are central to the poem, so any semantic change or deviation induces a probable translation shift and affects the target language interpretive potential.

The Slovenian translator's solution of the rhyme-refrain situation is close to optimal; the two refrain endings are translated as brez napora (Eng. effortlessly; the equivalent of isn't hard [to master]) and katastrofa (Eng. catastrophe, disaster), effectively replacing source-text rhyme with target-text assonance, which in this situation is a rational decision. The assonance could be argued as imperfect because of the different quality of the vowels (napôra, katastrófa); yet, the issue is minor in view of the complexity of the translation problem and solution. Save for

${ }^{13}$ The villanelle rhyming/repetition pattern is A1bA2 abA1 abA2 abA1 abA2 abA1A2, where repeated small letters denote rhyming lines, while A1 and A2 stand for the refrains, which also rhyme with all first lines and, obviously, with each other. 
two epistrophes, however, assonance consistently replaces rhyme in all other instances (the middle tercet lines include namena, dneva, streha, kontinenta, evidentna, and the remaining lines connected to the refrains include mora, znova, moja, ogromna, roka).

Apart from the Slovenian refrain ending choice katastrofa, the other three salient themes (loss, master and art) are translated as (izguba, mojstriti and umetnost). All four being internally interwoven, successful preservation of the interpretive potential of these four central themes (including art from the title) in Slovenian depends to a large extent on the target language lexical choices embodying the four concepts.

As the last formal aspect of the Slovenian translation of "One Art," we will investigate the latter's metrical and rhythmic characteristics, which are closely connected to its lexical aspect. The observation that almost all Slovenian expressions in the translated poem are longer than their English counterparts does not come as a surprise, since Slovenian texts are commonly longer than their corresponding English variants. The reasons for this can be mainly attributed to English being a predominantly analytical language, while Slovenian is chiefly synthetic. Moreover, English is more monosyllabic than Slovenian. In poetry, the length of words and lines is measured in number of syllables, and in the Slovenian translation of "One Art," practically all words have a higher number of syllables than their English counterparts. Additionally, these numbers may vary, i.e., often increase, according to the inflectional suffixes that change with the declension of adjectives and nouns, conjugation of verbs, changing of modal structures, etc. Consequently, the translator faces the near-impossible task of fitting the relevant corresponding concepts into the iambic pentameter line in Slovenian.

This can be illustrated on the example of the first line, which is the first refrain and loaded with relevant thematic concepts: "The art of losing isn't hard to master." The expressions supporting these concepts are art, losing, (not) hard and master. Matching these with semantically or conceptually appropriate Slovenian translations yields the following options:

\begin{tabular}{|l|l|l|}
\hline art (1 syllable) & vs. & u-met-nost (3 syllables) \\
\hline lo-sing (2) & vs. & iz-gu-blja-nje/nja (4); or iz-gu-ba/be (3) \\
\hline hard (1) & vs. & $\begin{array}{l}\text { tež-ak/ka/ko (2); or te-ža-ven/vna/vno (3); or zah-te-ven/ } \\
\text { vna/vno (3) }\end{array}$ \\
\hline ma-ster (2) & vs. & ob-vla-da-ti (4); or ob-vla-do-va-ti (5); or na-u-či-ti se (5) \\
\hline
\end{tabular}


Even though the existing translation of the first line is a combination of these and other translation choices, it is practically impossible to keep the number of syllables in the Slovenian verse the same or at least comparable to the original; in the existing translation there are 14, although these could be read in iambic pentameter with a conscious rhythmical adaptation (using three anapestic substitutions):

Moj-stri-ti u-met-nost i-zgu-be gre brez na-po-ra

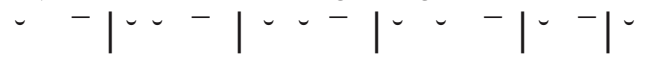

If, on the other hand, we observe one of the less easily adaptable lines, i.e., the last line of the poem "though it may look like (Write it.) like disaster," the syllable count yields 18 syllables, with one potential anapaestic substitution that cannot approximate or be fitted into the iambic pentameter scheme:

če-prav mor-da je vi-de-ti kot (za-pi-ši to) kot ka-ta-stro-fa

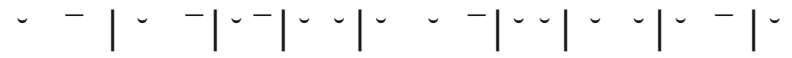

As illustrated with two sample lines, the metrical appearance of the translated poem cannot be fully satisfying, although the translator's endeavours are palpable and must be appreciated. It is also evident that the thematic aspect of the poem and certain formal features have been given priority, at least to a certain extent on account of rhythm and meter. It cannot be denied that the metrical looseness of the poem, particularly when measured against the perfectly framed form of the villanelle, is a slight disappointment for the reader, considerably watering down the "stand-out" effect distinguishing it from other poemswhich it has in the original; however, it will probably take several retranslation attempts that would favour and prioritize other features of the poem. We would like to close the translation analysis with a possible alternative suggestion for the translation of the opening line: "Umetnost izgubljanja ne terja mojstra," which arguably improves the aspect of meter and adds some thematic accuracy to the concept of losing (in the existing translation, "[ $\mathrm{t}]$ he art of losing" undergoes semantic change to become "the art of loss"), but it is sure to have other drawbacks, not immediately perceptible. 


\section{Conclusion}

After aligning Bishop's poem with the critical literature and with a century's worth of villanelle production, we have established that there are a few firm conclusions. First, Bishop did alter the development of future villanelles by introducing such radical variation in the repetends. The polysemic repetend appealed to the American New Formalists, as well as to contemporary villanelle writers. Beyond that effect, we found no quantifiable evidence that her poem affected the popularity of the poetic form, despite general critical and anecdotal support for this idea. Nevertheless, Bishop's near-memetic variability in the refrains, does seem to have exerted a schema-refreshing effect on subsequent villanelle production. Additionally, there has been a growth in both critical and popular attention to the poet and, overwhelmingly, to "One Art," which has escaped academic textbooks to become a global cultural property. Slovenian New Formalism has accorded the villanelle form considerable importance, and the existing translation supports our analysis of the poem's intricate schemata.

As suggested in the opening part of section 3, the metrical aspect of the Slovenian translation of "One Art" is the principal challenge of this translation endeavour. Unfortunately, yet not surprisingly, this part of the translator's task was not as successful as other aspects of the poem. The metrical looseness of the translated poem, particularly when measured against the perfectly framed form of the villanelle, is a slight disappointment for the reader. Paradoxically, the formal perfection of the villanelle, its fixed geometry, thus constitutes both its major attraction and a nearly insurmountable challenge for global translators.

\section{WORKS CITED}

Abrams, M. H., and Geoffrey G. Harpham. A Glossary of Literary Terms. Wadsworth: Cengage Learning, 2009.

Alkalay-Gut, Karen. "Overcoming Time and Despair: Ernest Dowson's Villanelle." Victorian Poetry 34.1 (1996). 101-107.

Baldick, Chris. The Oxford Dictionary of Literary Terms. Oxford: OUP, 2008.

Bennett, Bruce. "The Thing's Impossible." Ploughshares 37.2-3 (2011). 10-13.

Bishop, Elizabeth. The Complete Poems 1926-1979. New York: Farrar, Straus \& Giroux, 1983.

- - - Zemljevid. Ljubljana: LUD, 2000.

Cerne, Helen. "Villanelle, a Writer's Hell." Hecate: A Women's Interdisciplinary Journal 30.2 (2004). 124. 
Deacon, Kelly. Rhyme, Rondeau and Villanelle. Peterborough, UK: Anchor Books, 2000.

Ellingsen, Eric. “The Long Poem of Walking.” World Literature Today 85.1 (2011). 41-45.

Ford, Karen Jackson. "Weaving Close Turns and Counter-Turns: The Villanelle." A Companion to Poetic Genre. Ed. Erik Martiny. Chichester, Malden: WileyBlackwell, 2012. 172, 183-184.

French, Amanda L. "Edmund Gosse and the Stubborn Villanelle Blunder." Victorian Poetry 48.2 (2010). 243-266.

---. Refrain Again: The Return of the Villanelle. PhD dissertation, University of Virginia. Charlottesville, 2004.

Gadpaille, Michelle. "Metaphor, Meme and MacLennan's Two Solitudes." Individual and Community: Canada in the 20th Century. 2nd International conference of Central European Canadianists. Brno: Masaryk University, 2004. 19-25.

Geckle, George L. "Stephen Dedalus and W. B. Yeats: The Making of the Villanelle." Modern Fiction Studies 15.1 (1969). 87-96.

Hirsch, Edward. The Essential Poet's Glossary. New York: Houghton Mifflin Harcourt, 2017.

Hollander, John. "Breaking into Song: Some Notes on Refrain.” Lyric Poetry: Beyond New Criticism. Ed. Chaviva Hošek and Patricia Parker. Ithaca: Cornell University Press, 1985. 73-89.

Jarman, Mark. "Wedding Villanelle." The Hudson Review 61.1 (2008). 42.

Jason, Philip K. "Modern Versions of the Villanelle." College Literature 7.2 (1980). 136-145.

Kane, Julie. "The Myth of the Fixed-Form Villanelle." Modern Language Quarterly 64.4 (2003). 427-443.

Lawrence, Anthony. "Explaining Villanelles to an Alien.” Poetry 213.6 (2019). 558.

Magnus, Laury. The Track of the Repetend: Syntactic and Lexical Repetition in Modern Poetry. PhD dissertation, City University of New York. New York, 1979.

Mead, Matthew. "The Unrhymed Villanelle." Ambit 156 (1999). 49.

Millier, Brett Candlish. "Elusive Mastery: The Drafts of Elizabeth Bishop's 'One Art."” New England Review 13.2 (1990). 121-129.

Muldoon, Paul. "Moving on Silence: Yeats and the Refrain as Symbol." Yeats Annual 20 (2016). 155-177.

Northrop, Kate. “A Place above the River." American Poetry Review 39.4 (2010). 33.

Novak, Boris A. Mojster nespečnosti. Ljubljana: ZMK, 1995.

-- -. Oblike duha. Ljubljana: Mladinska knjiga, 2016.

Novak Popov, Irena. "Contemporary Slovenian Poetry in Literary Studies." Slavistična revija 61.1 (2013). 77-94.

Oak, Rachelle. “An Imperfect Villanelle." Beside the Point: Camosun's Literary Magazine 5 (2017). 30.

Parini, Jay. "The 10 Best American Poems." Guardian Online 11 March 2011.

Pavlič, Darja. "Contextualizing Contemporary Slovenian Lyric Poetry Within Literary History." Slovenian Studies 31.2 (2009). 161-170.

Ritchie, Elisavietta. "How to Write a Villanelle." Poetry 179.5 (2002). 270.

Roethke, Theodore. Collected Poems of Theodore Roethke. New York: Doubleday, 1953.

Roos, Bonnie. "Refining the Artist into Existence: Pygmalion's Statue, Stephen's Villanelle and the Venus of Praxiteles." Comparative Literature Studies 38.2 (2001). 95-117. 
Schneiderman, Jason. "The Literary Anatomy-Teaching the Villanelle: The Satellite and the Snowball." Teachers \& Writers 34.2 (2002). 9-13.

Segal, Ian. "Our Poets on Their Poems: Edward Hirsch's Rotating Refrain.” The New Yorker 10 March 2010.

Shapiro, David. "On a Villanelle by Elizabeth Bishop.” The Iowa Review 10.1 (1979). 77-81.

Spiegelman, Willard. "Heirs and Heirlooms: The Legacy of Elizabeth Bishop and James Merrill.” The Kenyon Review 13.2 (1991). 154-159.

Spivack, Kathleen. "Conceal/Reveal: Passion and Restraint in the Work of Elizabeth Bishop." The Massachusetts Review 46.3 (2005). 496-510.

Taylor, Marilyn. "Repeat Yourself-with Purpose: The Art of a Villanelle Inspired by Dance Lies in the Graceful Repetition of Two Key Lines." Writer (Kalmbach Publishing) 121.12 (2008). 15-16.

Vertreace, Martha Modena. "Sestinas and Villanelles from the Inner City." Teaching English in the Two-Year College 24.1 (1997). 47.

Woodland, Michael. "'Pursuit of Unsayables': Repetition in Kristeva's Black Sun and Strand's 'Two de Chiricos.'” Mosaic: An Interdisciplinary Critical Journal 37.3 (2004). 121-138.

\section{Elizabeth Bishop in vilanela: ena umetnost, ocean in dva jezika}

Ključne besede: ameriška poezija / Bishop, Elisabeth / vilanela / polisemični refren / literarno prevajanje / prevodi v slovenščino / Taufer, Veno

Povod za nastanek tega prispevka je znana pesem Elizabeth Bishop »Ena umetnost « (»One Art«), ki kot vilanela izstopa v sodobni poetiki: združuje dolgotrajno zapuščino modernističnega svobodnega verza in številne veje eksperimentalne postmoderne poezije v Združenih državah Amerike. Podobno kot Ted Roethke tudi Elizabeth Bishop priznava tradicionalno šestkitično pesniško obliko z angleškim poimenovanjem "villanelle« ali "vilanelle« kot primeren medij za izražanje razmišljanja razgledane peripatetične lezbične pesnice poznega 20. stoletja. Formalno gre za anahronistično prisvajanje; v estetskem smislu gre za triumf. Vprašanja, ki jih odpira pesem Elizabeth Bishop in si jih ta prispevek zastavlja, so predvsem tri: prvo se dotika ustreznosti obstoječe terminologije za opredelitev koncepta refrena - tu avtorja predlagava vpeljavo novega termina: polisemični refren (angl. polysemic repetend). Drugo vprašanje se posveča globalnemu vplivu pesmi »One art«. Nato prispevek obravnava prisotnost vilanele $\mathrm{v}$ slovenski poetiki ter se posveti slovenskemu prevodu vplivne vilanele »Ena umetnost«, saj je bil glede na 
formalno kompleksnost metrične sheme, rime in sistema refrenov za prevajalca Vena Tauferja nedvomno trd prevajalski oreh. Študija si tako prizadeva za razumevanje vzporednic $\mathrm{v}$ estetiki novega formalizma med ameriško in slovensko poezijo.

1.01 Izvirni znanstveni članek / Original scientific article UDK 821.111(73).09-1Bishop E. $81^{\prime 2} 255.4: 821.111(73)=163.6$

D0I: https://doi.org/10.3986/pkn.v42.i3.05 